\title{
High levels of alpha fetoprotein (AFP) production by a benign ovarian serous cystadenoma: a non-classic presentation
}

\begin{abstract}
Summary: The combination of a high serum AFP and ovarian mass typically guide the physician towards a differential diagnosis that includes gonadal germ cell tumors and certain types of teratomas. Here we present a previously undocumented phenomenon of a serous cystadenoma where, upon thorough pathological examination and staining, benign ovarian epithelial cells were found to be the source of a serum AFP level of greater than 900 $\mathrm{ng} / \mathrm{ml}$ (reference range of normal $0-10$ ).
\end{abstract}

Keywords: alpha fetoprotein (AFP), cystadenoma, serous cystadenoma
Volume 4 Issue I - 2016

\author{
Takeko Takeshige,' Shadi Rezai,' Annika \\ Chadee,' Richard Giovane, ${ }^{2}$ Cassandra E \\ Henderson,' Umeko Takeshige, ${ }^{3}$ Harvey \\ Sasken, ${ }^{4}$ Ray Mercado,' Sheyna E Gifford ${ }^{3}$ \\ 'Department of Obstetrics and Gynecology, Lincoln Medical \\ and Mental Health Center, USA \\ ${ }^{2}$ St. Georges University, West Indies \\ ${ }^{3}$ Gastroenterology, New York Institute of Technology College of \\ Osteopathic Medicine, USA
}

Correspondence: Takeko Takeshige, Lincoln Medical and Mental Health Center, 234 East 149th Street, Bronx, NY, I045I, USA, Email rezsha@sgu.edu

\section{Background}

Although the function of alpha fetoprotein (AFP) has never been fully described, quantitative changes in serum levels have been used as a clinical screening tool. Many pathologic conditions, such as hepatocellular or yolk sac tumors and neural tube defects. ${ }^{1}$. Although it is rare for a tumor of epithelial origin to produce alpha-fetoprotein, the possibility exists due to the nature of the human $r$ genetic code. Genetic mutations may give rise to a neoplasm that produce unexpected glycoproteins.

Cystadenomas are benign epithelial tumors that are hollow cystic masses typically found in the ovary, appendix and endometrium. ${ }^{1}$ They are classified as serous, papillary or mucinous depending on the predominant cell type. Serum levels of CA-125, CA19-9 and CP2 can be measured if a primary ovarian tumor is suspected with subsequent serial measurement to assess treatment response., ${ }^{2,3}$ These tumors markers are generally used with mucinous or serous tumors. We describe a case an AFP producing ovarian cystadenoma. This is a unique case as AFP is not expected to be elevated in an epithelial cell tumor.

\section{Presentation of the case}

In an attempt to confirm the etiology of the elevated AFP, repeated frozen sections and light microscopy of the resected mass were pursued. Cytopathology was indefatigably consistent with a benign cystadenoma. Peritoneal washings were negative for malignant cells. ALP and ALT had returned to the normal range. Liver enzymes, pancreatic enzyme, CEA and CA-125 remained unelevated. Panels for Hepatitis C viral PCR, Hepatitis B viral DNA, Hepatitis B Antigen, and Hepatitis B Antibody were all negative. Ultimately, $\mathrm{H} \& \mathrm{E}$ and AFP stains of sections from the serous cystadenoma surface were undertaken (Figures 1-3). These revealed a well-differentiated ovarian epithelium whose surface cuboidal cells stained deeply for AFP.

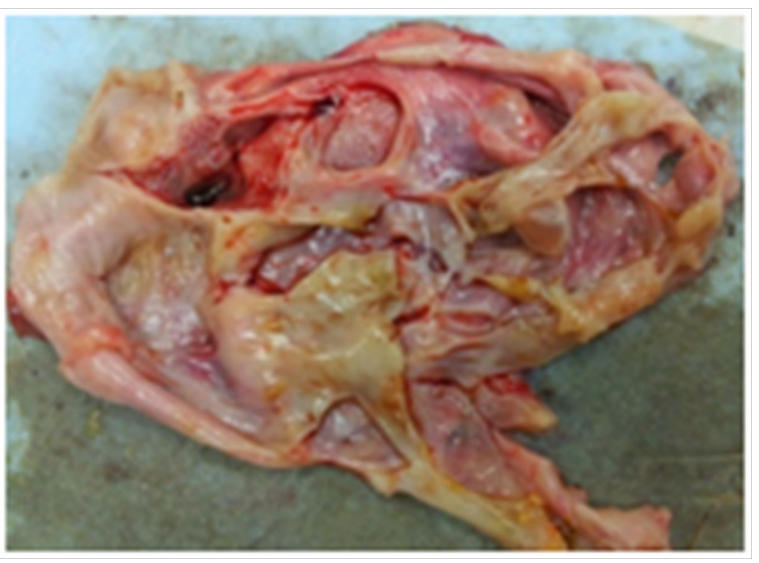

Figure I Gross adnexal mass immediately post-resection, with the fluid evacuated: showing multi-cystic structure with some mucinous material in the lining.

\section{Discussion}

Alpha-fetoprotein (AFP) can be classified as glycoprotein formed primarily by the fetal liver and detectable in the serum of healthy adults with a mean of $3.04 \mathrm{ng} / \mathrm{ml} \pm 1.9$ standard deviation (SD) ${ }^{4}$ Certain conditions can produce excess levels of AFP above the normal range. Examples include pregnancy, viral hepatitis infections, hepatic carcinomas, renal carcinomas, cells of endodermal sinus tumors and other non-seminomatous germ cell tumors ${ }^{5,6}$. During pregnancy, AFP levels are expected to reach their highest level in the early third trimester with a mean of $30.45 \mathrm{ng} / \mathrm{mL} .^{7}$. Certain pathologies such as yolk sac tumors, embryonal carcinomas and teratomas are known to produce levels of AFP in excess of $900 .{ }^{8,9}$ Furthermore, levels of AFP can reach levels exceeding 200,000 with neoplasms involving the renal and hepatic systems..$^{10,11}$ 


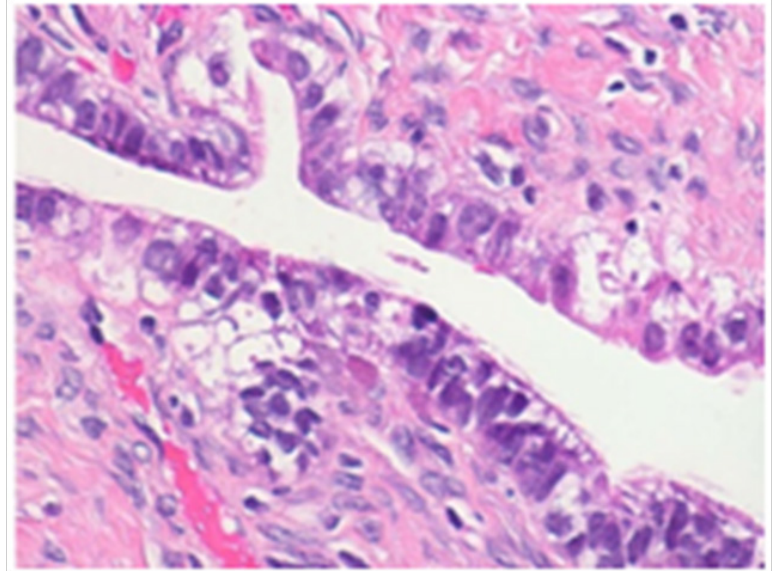

Figure 2 Lining Ovarian epithelium with Hematoxylin and eosin stain (H\&E stain), showing cells containing some secretory materials and well differentiated cuboidal epithelium.

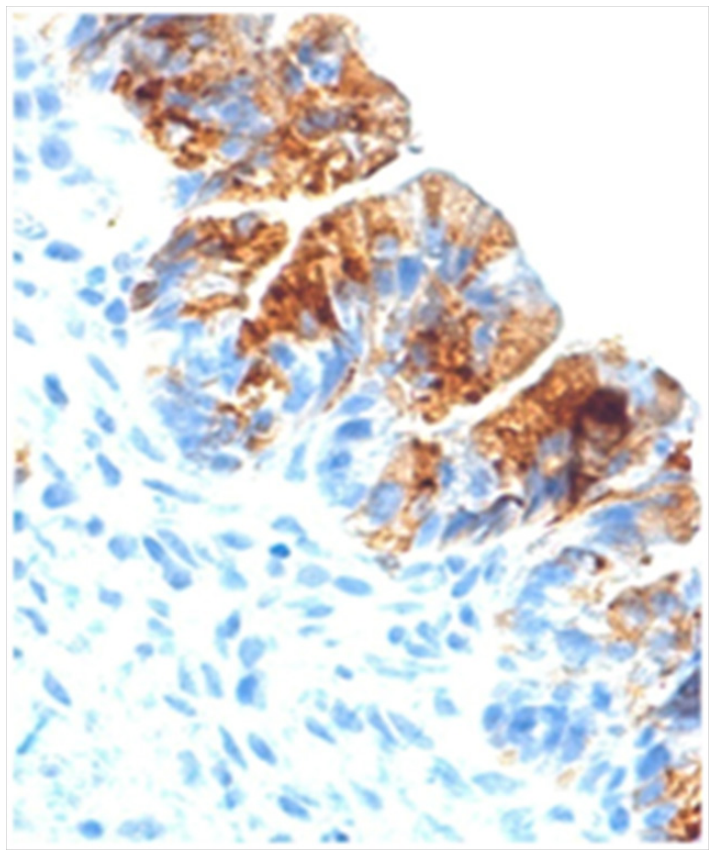

Figure 3 Immunohistochemical stain for Alfa fetoprotein (AFP stain) of the lining epithelium of the surface of the ovarian cystic mass (serous Cystadenoma of the ovary): The epithelium consisting of well differentiated cuboidal cells stained deeply and globally for AFP.

The standard half-life of AFP is taken to be seven days. ${ }^{12}$ but when used as a prognostic tool in tumor therapy, AFP levels are known to rapidly decline in such a way that it reflects the completeness of tumor resection. In comparison, completely resected tumors without recurrence have an actual half-life (AHL) of AFP that has been estimated to be 4 days $+/-0.9$; while in non-complete resections with high rates of recurrence, the AHL was reported to be $24.8 \pm 20$ days. ${ }^{13}$ In this case report serial blood draws demonstrated a drop in AFP levels consistent with what would be expected when an AFP-producing mass or tumor had been removed in its entirety. Forty-three days after mass resection, the levels of AFP in this patient's serum were virtually undetectable $(2 \mathrm{ng} / \mathrm{ml})$. Therefore, the source of the AFP in this patient was definitively the resected mass.
The 600 gram smoothly loculated mass that had been removed from the patient bore no morphological resemblance to an endodermal sinus tumor. Morphologically, endodermal sinus tumors of the ovary are small (average $15 \mathrm{~cm}$ ) and solid with tan, yellow or grey cut surfaces. ${ }^{14}$ Histologically, they show high mitotic activity, SchillerDuval bodies and stromal luteinization. ${ }^{15}$ Our patient's mass was consistent in every way with serous cystadenoma: it was large in size, with a thin-walled sac-like consistency, filled with fluid, loculated, smooth and histologically displayed only well-differentiated cuboidal epithelial cells. No mitosis or luteinization was noted. With the rapidly diminishing level of AFP pointing to this benign mass as the source of the very high AFP, it was decided to stain the ovarian epithelial cells for AFP.

Although AFP is known to be a glycoprotein which is a product of fetal liver and hepatic origin, these benign epithelial cells proved themselves to be the source of our patient's AFP. The majority of the cells lining the surface of this patient's cystadenoma demonstrated the presence of AFP. This finding, which has never been noted in the medical literature, is an elegant reminder that each cell in our body contains most if not all of the same DNA as every other cell. Signaling mishaps, misallocation and minor shifts in activation systems can convince one cell take on the characteristics of another. In this case, we have presented a thirty year old patient with a large benign ovarian mass that bore no clinical or functional resemblance to a classic AFPproducing tumor endodermal sinus tumor, yet was producing AFP on a level consistent with such a malignant ovary. Careful followup of this patient, a stepwise clinical plan, serial labs and strategic pathological studies executed over a six week time-span spared this patient from expensive, invasive and unnecessary procedures while locating and explaining the remarkable source of her high serum alpha-fetoprotein.

\section{Conclusion}

The use of tumor markers as a diagnostic approach in a patient with a primary tumor or charting a response to treatment is an invaluable diagnostic tool. Several tumor markers have been described as being associated with different tumors. Tumors which produce glycoproteins that are not characteristic of the tumor, reminds clinicians of the infinite potential a cell has via the genetic code that it carries. Clinicians should always be aware of the chance of genetic mutations in a patient which can result in an unexpected manner of how the patient will present or what is found through laboratory studies.

\section{Acknowledgments}

None.

\section{Conflicts of interest}

The authors declare there is no conflict of interests.

\section{Funding}

None.

\section{References}

1. Kumar V, Robbins SL. Text book of robbins basic pathology. 8th edn. Philadelphia, PA, USA: Elsevier Saunders; 2007.

2. Dong L, Cui H, Li XP, et al. Clinical value of serum CA19-9, CA125 and CP2 in mucinous ovarian tumor: a retrospective study of 273 patients. Zhonghua Fu Chan Ke Za Zhi. 2008;43(1):5-8. 
3. Alanbay I, Aktürk E, Coksuer H, et al. Comparison of tumor markers and clinicopathological features in serous and mucinous borderline ovarian tumors. Eur J Gynaecol Oncol. 2012;33(1):25-30.

4. Ball D, Rose E, Alpert E. Alpha-fetoprotein levels in normal adults. Am J Med Sci. 1992;303(3):157-159.

5. Richardson P, Duan Z, Kramer J, et al. Determinants of serum alphafetoprotein levels in hepatitis C-infected patients. Clin Gastroenterol Hepatol. 2012;10(4):428-433.

6. Jagiełło-Wójtowicz E, Rzeszowska G, Krawczuk G, et al. Alphafetoprotein in acute viral hepatitis type A. Przegl Epidemiol. 1993;47(1-2):17-20.

7. González-Bugatto F, Foncubierta E, Bailén Mde L, et al. Maternal and fetal serum transformed alpha-fetoprotein levels in normal pregnancy. $J$ Obstet Gynaecol Res. 2009;35(2):271-276.

8. Akaza H, Kameyama S, Aso Y. Significance of tumor markers in the treatment of urological malignancies. Gan To Kagaku Ryoho. 1987;14(11):3034-3040.
9. Bast RC Jr, Badgwell D, Lu Z, et al. New tumor markers: CA125 and beyond. Int J Gynecol Cancer.2005;15(3):274-281.

10. El-Bahrawy M. Alpha-fetoprotein-producing non-germ cell tumors of the female genital tract. Eur J Cancer. 2010;46(8):1317-1322.

11. Kudoh K, Kikuchi Y, Kita T, et al. Preoperative determination of several serum tumor markers in patients with primary epithelial ovarian carcinoma. Gynecol Obstet Invest. 1999;47(1):52-57.

12. Diamandis EP, Fritsche HA, Lilja H, et al. Tumor markers: physiology, pathobiology, technology, and clinical applications. Washington, DC, USA: AACC Press; 2002.

13. Han SJ, Yoo S, Choi SH, et al. Actual half-life of alpha-fetoprotein as a prognostic tool in pediatric malignant tumors, Pediatr Surg Int. 1997;12(8):599-602.

14. Saygili U, Uslu T, Erten O, Doğan E. Borderline ovarian tumors: retrospective analysis of twenty-one cases. Eur J Gynaecol Oncol. 1998;19(2):182-185.

15. Kurman RJ, Norris HJ. Endodermal sinus tumor of the ovary: a clinical and pathologic analysis of 71 cases, Cancer 1976;38(6):2404-2419. 